\title{
Enabling learners of a non-native language to auto-diagnose their learning inhibitions and disabilities
}

\section{Amal Mahmoud Elmatarawy (Ph.D)NCERD Researcher}

Within the framework of raising self-awareness the" Kai-KaKou" Japanese systematic approach has been manipulated to enable learners figuring out what hinders their communicative process and leads to inhibit learning. To do this, an instrument has been designed to stand as a "must-have" manual. This manual instrument has a double- fold objective. First, auto-diagnose what hinders communication and thus inhibits learning. Second, provide procedures and steps for a learner to adopt and resolve this communicative learning dilemma. This manual addresses raising learners' self-awareness. This has been facilitated through adopting the Japanese "Kai-Ka-Kou" systematic approach mainly for the following reasons. First, it is a four-capsulated steps. Second, it targets the learners' thinking map leading to a " radical-processchange". Third, it facilitates auto-diagnosing through being capsulated in its designing characteristics. Fourth, it facilitates designing an individualistic measuring tool.

In designing a "must-have" manual, learners of English as a non-native language has been addressed. A particular emphasis is given to learners who expressed a need to bridge the gap between being able to communicate virtually and being hindered to communicate in a face-to-face real life living communication. Alerting learners to what might cause this felt gap has been crystallized throughout the processes of the "must-have" manual.

\section{Problem}

Some learners of English as a non-native language have expressed a need to easily communicate in the targeted non-native language. They maintained an ability to virtual communication and a disability in real life communication as expressed. For those learners the word easily refers to getting their purposed goal attained using the non-native language they are learning through either the written corpus or the oral one. To some of them virtual communication in the non- native language is much easier than the real living communication. For those learners the underlying reason beyond this dilemma is not crystal clear. Accordingly, the need to investigate reasons beyond being unable to communicate in

\section{1}


real life situation using a non-native language has been raised. Thus, a need to auto-diagnose learning inhibitions and auto-resolve them has been established.

\section{Rationale}

Based on the above, communicating in a non-native language has been considered a problem for learners participated in this study. For those learners using English for real life communication is of utmost importance. Some of them need it for furthering their studies; others need it for work promotion purposes. Those participant learners have indicated that they can communicate in the non-native language via electronic media. They expressed the need to identify reasons beyond hindering their communicative learning abilities. To explore those reasons, the study attempts to question the feasibility of using the Japanese Kai-Ka-Kou as a systematic self- awareness approach in autodiagnosing learning inhibitions and communicative disabilities.

\section{Questions}

Thus, whether Kai-Ka-Kou as an independent variable represented in the "must-have" manual would help in auto-diagnosing what inhibits learning English and what hinders communicating in English as dependent variables is targeted in this study.

\section{Limitations}

This study is limited to learners of English as a non-native language. It is also limited to learners who have expressed the need to auto-diagnose their learning inhibitions and communicative disabilities. A third limitation is manipulating the Japanese Kai-Ka-Kou systematic approach in raising learners self-awareness and in designing the " must-have" manual.

A description of what Kai-Ka-Kou entails for purposes of this study will be clarified below.

\section{Literature review}

Based on the assumption that learners are not identical and that learning is a personal individualistic experience, it is expected that reasons beyond learning inhibitions will consequently differ. That is why a focus on an auto- diagnostic identification of a learning inhibition or a learning 
disability has been attempted. This necessitates an ability to spiritually raise self power of the participated learners. In agreement to Chopra(2012), the learner has to realize first, that there is something wrong somewhere and second, that he or she could do something about what is considered wrong. These two phases would consequently lead to spontaneous resolution to what inhibits communicative use of English in real life. In agreement to what Chopra ( 2012) maintains, spiritual self power could be raised if three levels of awareness have been realized. The first level is tagged as contracted, the second level is tagged as expanded and the third one is tagged as pure awareness. This study focuses on self-awareness tagged as pure awareness in Chopra (2012).

For purposes of this research, what Chopra (2012) maintains could be specified as the mind thinking map represented through the Kai-Ka-Kou Japanese systematic approach. A lot of research has, as well, indicated the importance of self awareness in supporting autonomous learning. Rinkevičiene\& Zdanye (2002) maintained that to be inhibited to learn or be disable to learn should be examined through the individualistic perspective of every participant learner through raising awareness. In this study the graduate participant learners who expressed their need to know what hinders their communicative aspects in real life situations were alerted through the " must-have" manual particularly designed to fulfill that purpose. For those graduate learners virtual non-native language communication is much more easier, feasible and attainable. Peters (2012), explains success in carrying out a task with reference to the psychological mind a person might have. Thus, the mind thinking map of a learner is of utmost importance in achieving goals. The psychological mind has been described as having two independent thinking machines; one is human in nature, the other is a chimp in nature and both of used to interrupt experiences. For purposes of this study, the learners' mind map has to be changeable. Basically, this study considers what hinders learning or inhibits communication to be due to either external factors or internal ones or both external and internal elements.

To investigate reasons beyond what hinders the communicative aspects of English in real life situation an investigation into language real and right practices should be made. This entails designing an instrument tailored to attain this purpose. This instrument would elaborate on learners' right practices and right understanding for these practices. 
Cunningham, 2011, maintains that we are all responsible for our actions. This entails that taking an action to learn a non- native language is the responsibility of nobody but the learner. This supports the idea of pure awareness which has been maintained by Chopra (2012) as previously mentioned.

\section{Method}

Within the framework of the "Kai-Ka-Kou" Japanese systematic approach, the qualitative descriptive method of research has been adopted. An instrument has been designed to enable a learner of English as a non-native language identifying his/her learning inhibitions and disabilities. This instrument helps the learner to get to the real reason or reasons beyond what hinders learning. This instrument covers five main parameters detailed as follows: the linguistic parameter, the applied thinking parameter, the socio-economic parameter, the socio-cultural parameter, and the cosmopolitan socio- pragmatic parameter.

\section{Instruments}

A "must-have" manual has been designed to fit for the Kai-Ka-Kou and the five parameters addressed in this study. Below is a detailed item description of each parameter and how each item is manipulated .

\section{The linguistic parameter:}

This covers the linguistic aspect of the language in both its written and oral manifestations which forms the "mind-thinking-map" of the participant learner. To help auto-diagnose the written aspect of a learning inhibition or a disability in communicative writing, the learner has been asked to write a journal dialogue expressing how he feels or how something very special and relevant to him could be done. $\mathrm{He} / \mathrm{she}$ is required to do this task for at least five consequent days. He/she is also required to sit for a five- minute- writing task every day. The timeline, i.e., " the when" during a day, and the topic ,i.e., "the what" to write is left to the learner to identify for him/her self. Getting at a learning inhibition is enabled through the repeated writing alerts administered. To help auto-diagnose the oral manifestation, the learner has been asked to record for himself /herself what he/she says or utters. He /she can do this through recalling, memorizing, or reading aloud. Whatever medium is considered perfect as long as the purpose of recording is attained. 
Listening back to what has been recorded will be left to the learners' choice to identify the "when" time. Appropriate time set for listening back is confidentially kept by learner. The threshold level is set and prioritized on an individualistic basis.

\section{The Applied thinking parameter}

This parameter measures what practices have been made to arrive at the targeted goal, namely, not being inhibited to learn and/ or being able to communicate using English for real life and/or work purposes.

This parameter entails various practices. These practices lead to a change in what ought to be done to further the linguistic practices of English being the non-native language of the participant addressed in this study. Applied thinking practices reflecting aspects of being committed, confident, meticulous, mindful, non-judgmental, open- minded, and responsible for learning and thinking practices. Other practices entails becoming a good listener and a good time-manager. A sheet explaining the applied thinking practices targeted as well as explaining the practiced task and the level to be measured and attained is administered to the participated learners.

\section{The socio-economic parameter}

This parameter, according to the participated learner is beyond their communicative disability. That's why the "must-have" manual explains how to get to the target without being hindered.

It focuses on the language of deletion to be avoided. It entails a change in the "mind map" concerning asking for missing information. This is clarified through the huge number of questions one might ask and annoy people. Questions about who, what, when, why, and how which might really annoy others. These questions might end up with losing a targeted job or career, thus affecting the socio-economic status of the participated learner. Accordingly, to "put-at-work" the targeted "mind map" mentioned before, an awareness for the intended deleted information is raised. Four main deletion language patterns are considered:

- unspecified verbs, adverbs and adjectives,

- unspecified comparisons,

- unspecified people, and

- abstract nouns. 
In real life communication, probing to uncover information would lead to hindering the socio-economic communicative aspect.

\section{The socio- cultural parameter}

This parameter is closely related to understanding what language to use in a specified task. Idiomatic expressions would sometimes lead to social misunderstanding. When to use and what to use necessitates the following:

-perceptual positions: to see both perspectives and to help in considering other's perspective

-consider relationship and mutual understanding strategies, and -consider frequent changes.

\section{The cosmopolitan socio-pragmatic parameter}

This parameter entails inhibitions caused through distortion. This occurs when something is mistaken for that, which it is not. It might also happen when things which have not occurred are included in the internal representation of the participant learner. To avoid this distortion the "must-have" manual provides steps to auto-diagnosing various sources that might cause distortion.

\section{Participants}

Participants were 145 learners of English as a non-native language enrolled in English language courses in various learning institutions. Learners participated have expressed their need to identify reasons beyond their disability to use English to communicate for real life purposes. They belong to a variety of working domains. Some work for the media domain(40), some work for the banking domain(46), others are still enrolled in basic stage schooling education domain(59).

\section{Results}

Results have reflected the importance of manipulating the Japanese systematic "Kai-Ka-Kou" approach in raising learner's self-awareness concerning what hinders communicative aspects when using English as a non-native language in real life various capacities. Participants working for the media domain $(82 \%)$ indicated that the "must-have" manual has helped in getting their goal attained with respect to the linguistic parameter. Participants working for the banking domain (66\%) indicated

\section{6}


the "must-have" manual has enabled auto-diagnosing a socio-economic inhibition which resulted in a disability in the communicative real life manifestations. They also indicated that the linguistic parameter and the applied thinking one have enabled a realization of what caused misunderstanding in their workplaces (56\%). Participants still enrolled in basic stage schooling education domain have supported the use of the "must-have" manual in auto-diagnosing the linguistic communicative inhibitions (93\%). A call for having an auto-diagnosing communicative manual has been supported(95\%). The "must-have" manual has been considered a success in enabling learners auto-diagnose learning disabilities and communicative inhibitions (78\%).

\section{Interpretations}

Participants working for the media domain proved a great interest in the linguistic parameter. This could be justified for with reference to working prerequisites and demands. This could also justify for the banking participants who proved to be in favor for the socio-economic parameter, the socio-cultural parameter and the cosmopolitan sociopragmatic parameter. Schooling enrolled participants favored the linguistic parameter since it helped in enhancing their communicative learning manifestations. This in turn, would help in scoring high in their schooling exams.

To conclude, results reflected that the "must-have" manual designed and tailored to enable auto-diagnosing learning inhibitions and communicative disabilities has proved the importance of tailored individualistic learning as well as raising self-awareness through manipulating the Kai-Ka-Kou systematic Japanese capsulated approach.

\section{References}

- Boyes, C. (2010). NLP Secrets. Harper Collins. Canada

- Chopra ,D. (2012). Self Power. Harmony Books. USA.

- Cunningham, D.(2011). Pure Wisdom. Great Britain.

- Lazarus, J.(2010). Successful NLP. Great Britain.

- Terry, H.\& Wootton, S.(2010). Train Your Brain. UK.

- Peters , S. (2012). The Chimp Paradox. Vermilion . London .

- Wikipedia. (2011). mhtml: file://E:/Kai-Ka-Kou-, the free encyclopedia, Kai-Ka-Kou

- Rinkeviciene, I.\& Zdanyte, J.(2002). Raising students awareness in language learning. In Studies about languages. No.3 ISSN. 16482824. 


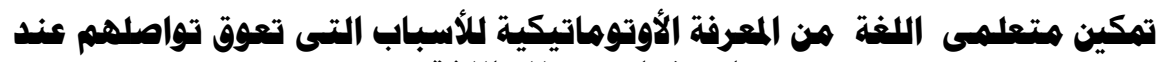

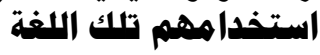

د / آمال محمود المطراوى

• مستخفص البحث باللغة العربية :

تهدف هذه الدراسة إلى التوصئ إلى تمكين متعلمى اللغة الأجنبية من التواصل باستخدام

تلك اللغة عند الحاجة الى ذلك ـوقد انبثقت فكرة الدراسة بناء على شكوى البعض منهم من القدرة على التواصل فى العالم اللافتراضى دون غيره.

وقد استهدفت الدراسة زيادة وعى المتعلم بالأسباب التى تحول دون تواصله عن طريق بطاقة

ثخحصية يستخدمها المتعلم صممت خصيصا لهذا الغرض. واعتمدت هذه البطاقة فى تصميمها ملى مدخل "كاى كا كو" اليابانى الذى يتخذ الخرائط العقليـة أساسـا للتغيُر والتفيير والتفاعل والنمو. وقد تم بناء البطاقة بحيث تتيع فرص التفردّد والنمو الأوتوماتيكى لكل متعلم على حله ـ واشتملت البطاقة على خمس محاور مرنه فرديه متمثلة فى محور للتراكيب اللغوية وآخر لتراكيب التفكير التطبيقى وثالث للتراكيب الاقتصادية الاجتماعية ورابع للتراكيب الثقافية الاجتماعية وخامس للتراكيب المجتمعية النفعية ـووقد استخدمت الدراسة الأسلوب الكيفى فى التطبيق وتحليل البيانات والذى أسفر عن أهمية وعى المتعلم بمعرفة مدى تواصله وإدراكه لإمكاناته التى تتيح له القدره على التواصل وان هذا الإدراك والوعى الذاتى قد أسفرعن إيجابية التواصل باللغة الأجنبية والذى أدى بلدوره إلى إنجاح عملية التواصل لدى أفراد عينة الدراسة بنسب متسقة مـع أهداف كل فرد على حده.

\section{溇溇溇溇潾}

\section{8}

Journal of Arabic Studies in Education \& Psychology(ASEP) 